Хренов Н.А.

\title{
Кино и город: фольклорный образ праздничного разгула в ранней кинематографической рецепции
}

Аннотация: Предметом исследования в данной статье являются мифологические подтексты, определяющие восприятие реципиентом конкретных фильмов, созданных многими режиссерами в разные эпохи. Эти подтексты активно влияют на сознание массовой публики, но при этом не осознаются. Содержанием массовой рецепции кино являются, в том числе, внекинематографические проявления коллективного бессознательного. В ней актуализируются ментальные проекции образов-архетипов, возникших в разные эпохи истории культуры и связанные с утопическими представлениями, мифами, религиозными символами. Причем, проекциям коллективного бессознательного на кинематограф предшествуют проекции на город, которые затем переносятся и на кино. В конечном счете, кинематограф как таковой оказывается грандиозным интертекстом, в котором получает отражение история культуры как в ее осевом, так и в доосевом выражении. Предмет анализа в статье сводится к проекциям, ставшими реальными уже на ранних этапах истории кино. Для выявления мифологических и архетипических подтектов в рецепции кино применяется методология таких научных дисциплин, как рецептивная эстетика, психоанализ и аналитическая психология. Основными выводами проведенного исследования являются следующие: а. в структуре посещаемости раннего кино преобладают те слои городского населения, которые сохраняют в своем сознании фольклорные стереотипы; б. восприятие города происходит в соответствии с фольклорным стереотипом праздничного разгула как синонима свободы; в. проецируемая массовым сознанием на город аура определяет, в том числе, и рецепцию кино. Вклад автора в исследование кинорецепции связан с распознаванием образа кино, на который переносится миф города. Новизна исследования заключается в выявлении существующзи в сознании реципиентов специфических архетипов, актуализируемых при восприятии кино.

Ключевые слова: Кинематограф, город, миф, фольклор, рецепция, архетип, праздник, утопия, лиминальность, обряд.

Review: The subject of the present research is the mythological subtexts that define how particular movies and films created in different periods are perceived by the audience. According to the author, these subtexts have a strong influence on mass consciousness of public, however, public is usually unaware of such influence. Among other things the content of mass reception includes out-of-cinematographic manifestations of collective unconscious. Mental projections of archetypic images which came into existence in different periods of cultural history and connected with utopian visions, myths, and religious symbols are coming to the fore. Noteworthy that projections on the city are precede the projections of collective unconscious on the cinema; they are transferred into the cinema later on. Finally, the cinema in principal makes a colossal intertext in which cultural history is reflected both in its axial and pre-axial aspects. The scope of analysis comes down to the projections which become realistic already at early stages of cinematography history. To define mythological and archetypical subtexts of cinematography reception, the author of the article has used methodology of such academic disciplines as receptive esthetics, psychoanalysis and analytical psychology. The main conclusions of the research are the following: a) the structure of the audience of early cinematograph was made up mostly of urban social groups which had folklore stereotypes in their consciousness; $b$ ) the city was perceived in accordance with the folklore stereotype of the festive revelry as a synonym for freedom; c) the aura around the city created by the mass consciousness defines many things including how cinematography is perceived. The author's contribution to the topic of cinematography reception is the recognition of the image of cinema containing the myth of the city. The novelty of the research is caused by the fact that the author of the article describes specific archetypes that exist in the mind of the audience (recipients) and become evident in the process of cinematography perception.

Keywords: Rite, liminality, utopia, holiday, archetype, reception, folklore, myth, city, cinematography. 


\section{1. Публика кино в ее отношении к городской массе рубежа XIX - XX веков.}

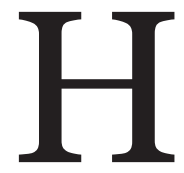

е прошло и столетия после того, как В. Белинский убеждал «Ходите в театр», как А. Белый, словно подхватывая эстафету, призывал: ходите в синематограф [2, с. 353]. Этот призыв озвучен поэтом в 1907 году. Он уже свидетельствовал о высоком статусе кино, возможности которого возможности театра явно превосходили. Мгновенному приему кино самыми массовыми слоями городского населения во многом способствовала создавшаяся к этому времени ситуация - увеличение за короткое время численности городского населения.

Уже на протяжении XIX века было очевидно, как начинает таять население деревни, которое тогда составляло большую часть населения России и еще продолжало сохранять средневековые традиции жизни, в частности, связь с землей. Ритм Развивающегося индустриального общества способствовал втягиванию массы деревенского населения в города. Исследовавший этот вопрос А. Вебер, привлекая массу статистики, констатировал: в течение XIX века число крупных городов увеличилось ужасно, а в них - численность населения. В античных городах численность населения достигала более 100 тысяч. Правда, численность, например, Рима равнялась 6о0-80о тысячам. Аристотель считал, что в плане численности жителей идеальным городом может быть лишь город, численность которого составляет 10 тысяч жителей. Плутарх предостерегал от перенаселенности городов. Но на рубеже XIX-XX веков городская культура во всей Европе превзошла все ожидания. Демографы доказывали, что, например, Лондон не должен превышать 5 миллионов жителей. Но уже в 1895 году его жителей насчитывалось более 6 миллионов [5, с. 445].

Рост городского населения за счет мигрантов вызвал к жизни новое образование в городском пространстве, которое назвали массой, городской массой. Некоторые исследователи утверждали, что это образование особого качества. Это уже не народ, а именно масса. Естественно, что исследование рецепции раннего кино невозможно без представления о морфологии массы, какой она впервые десятилетия XX века предстает. Посвящая свою работу вкусам городской массы, как они проявляются в реакциях на фильмы, К. Чуковский в 1910 году утверждал, что ки- нематограф как новую форму соборного творчества создает уже не создавший величайшие произведения фольклора народ, а городская масса. Это творимое массой новое соборное творчество является качественно иным. Традиционные формы фольклора угасли вместе с покидающим деревни крестьянством, т.е. народом. То же, что предстает в кинематографе, является порождением города и городской массы. «Но на другом конце нашей культуры, в ту же самую секунду, стал слагаться новый сплошной быт, - пишет К. Чуковский - новое множество, новое сонмище, новое скопище людей сгрудилось в новое тело - город. И чуть создался этот сплошной быт, создались и новые возможности для соборного творчества. Соборное творчество без сплошного быта немыслимо. И город, сделавшись городом, стал творить свой собственный эпос, и вот этот эпос в кинематографе» [25, с. 30].

Городская масса возникает как следствие отрыва от традиционной общности. Эта последняя постепенно распадается, уступая место тому образованию, что возникает в городах. Разрыв с традиционной общностью - исходная точка образования новых психологических признаков массы, которые и позволяют говорить о возникающем в городе новом ее качестве. Возникает необходимость выявить эти новые признаки городского образования, т.е. массы и, соответственно, массового сознания. Конечно, в этом направлении многое сделано социологами, философами и психологами. Но из виду важно не упускать то, что история образования и функционирования в городах массы - это не статическое состояние, а процесс. Следовательно, здесь важно рассматривать массовое сознание в соответствии с принципом историзма. Хотя массовое сознание - реальность, в которой бессознательное преобладает над сознательным, а вечное, повторяющееся над временным, тем не менее, в нем можно выделять последовательно возникающие в историческом времени фазы.

Конечно, о морфологии массового сознания, как и о его привязке к историческим обстоятельствам многое сказано Лебоном, Ортегой - и - Гассетом, Арендт, Каннети и Райхом, тем не менее, есть возможность для познания массового сознания воспользоваться наблюдениями над художественной жизнью. Реакции массы на отдельные произведения, будут ли они свидетельствовать о единодушном их приеме или, наоборот, об отторжении, конечно, позволяют сделать знакомые наблюдения 
над массовым сознанием и таким образом продвинуться в понимании его природы и его особенностей. Правда, в этом случае мы вроде бы ограничиваемся исключительно проблематикой массового сознания, а интересующий искусствоведа предмет при этом оказывается второстепенным. Но это не так. Дело в том, что реакции массы на произведения искусства для самого искусства не проходят бесследно. Они влияют на его эволюцию, изменяют логику его развития.

Если принимать во внимание активность массы в художественном процессе, то мы обнаружим, что под воздействием массовых реакций искусство начинает культивировать некоторые сюжеты и некоторые жанры. Оно начинает свидетельствовать о существующем отборе художников. Конечно, существует логика самодвижения и саморазвития искусства. Но эту логику обычно осознает творческая элита, способная вмешиваться в нее и вносить поправки. Это особенно касается такого подинститута как критика. Конечно, публика тоже воздействовала на искусство и в предшествующие эпохи. Эту закономерность можно проиллюстрировать на примере функционирования других искусств. Скажем, на примере театра. Известен, например, факт из истории театра XУІІІ века, вдохновлявшегося эстетикой классицизма. Исходя из этой эстетики и подражая Вольтеру, А. Сумароков писал трагедии, и они ставились в театре. До некоторого времени они смотрелись и высоко оценивались. Но неожиданно публика перестала их смотреть, что для А. Сумарокова, отвечающего в России за театральную политику, было неожиданностью. Он продолжал доказывать, ссылаясь на авторитет Вольтера, что лучше трагедии ничего не существует. Между тем, публика уже восхищалась мелодрамой.

Однако применительно к рубежу XIX $\mathrm{XX}$ веков вопрос о вмешательстве критики в художественную жизнь и об активности публики в этой жизни следует ставить совершенно иначе. Если нас интересуют первые десятилетия XX века, а мы как раз на этом периоде и останавливаемся, то здесь следует иметь в виду, что в этот период имеет место беспрецедентный факт, а именно, оттеснение массой элиты. Применительно к этому времени недостаточно констатировать активность массы в художественной жизни, что утверждается представителями рецептивной эстетики. Рубеж XIX - XX веков - это беспрецедентная эпоха, когда элита перестает играть определя- ющую роль в художественной жизни, а масса, лишаясь поводыря по этой жизни, начинает активно заявлять о своих эстетических и художественных предпочтениях, требуя от искусства их удовлетворения. Именно эту закономерность и выявил впервые Г. Лебон как один из первых аналитиков массового сознания, труд которого, как свидетельствует журнал «Театр и искусство», в России был прочитан. В соответствии с психологией масс уже в конце XIX века имела место попытка осмыслить реакции массовой публики в сфере театра [17, с. 99]

Собственно, это радикальное изменение в отношениях элиты и массы, которое произошло на рубеже XIX - XX веков, и определило наш выбор периода в эволюции массы. Отныне масса не только демонстрирует свою предельную активность в художественной жизни, но и диктует специфический репертуар, определяет выбор тех или иных сюжетов и жанров. Конечно, формулируя так проблему, мы как бы ставим искусство в полную зависимость от массы. Это, конечно, не так. Элита продолжает существовать и, более того, определять процессы и истории искусства, и даже истории кино. Не случайно имена представителей элиты этой эпохи использовались в кинорекламе. Скажем, в 1915 году студия И. Ермольева выпустила фильм «Не подходите к ней с вопросами», поставленный одним из самых известных в это время режиссеров Я. Протазановым с участием И. Мозжухина. Название фильма воспроизводило строчку из стихотворения А. Блока «На железной дороге». Фильм, конечно, ничего общего не имел со стихотворением А. Блока. Да и экранизация его была предпринята без ведома и разрешения поэта. Он, конечно, возмущался и протестовал [10, с. 138].

Более того, именно на рубеже XIX - XX веков в России начинается творческая вспышка, которую некоторые называют даже русским или славянским Ренессансом. Хотя относительно этой эпохи нельзя быть исключительно категоричным. Кому-то ситуация казалась Ренессансом, а кому - то декадансом, т.е. упадком. В реальности было и то, и другое. И Ренессанс, и декаданс имели место на фоне распада империи. Собственно, в этот период само возникновение массы стало следствием, с одной стороны, разложения доиндустриального общества, о чем свидетельствует увеличивающееся число мигрантов в города, a, с другой, разложением империи, в формах которой до этого времени существовала Россия как тип цивилизации. 
После характеристики сложившейся на рубеже XIX - XX веков исключительной ситуации можно перейти к более детальному анализу структуры массового сознания и разных ее уровней. При этом для более детальной характеристики массового сознания мы воспользуемся искусством. Реакции массы на искусство свидетельствуют о существенных признаках массового сознания. Более того, некоторые проявления искусства этого времени предстают институционализацией ментальности массы в ее эстетических проявлениях. Для решения этой задачи мы выбрали, прежде всего, кинематограф, точнее, реакции массы на кинематограф. Этот наш выбор объясняется тем, что в начале XX века кинематограф свободен от предшествующего опыта, от логики самодвижения, от инерции применяемых дотоле в этом виде искусства художественных приемов. Ведь в начале $\mathrm{XX}$ века кинематограф только и начинает свою историю. В отличие от других, традиционных искусств он не успел сформировать свою критику, своих ценителей и знатоков и, соответственно, свою публику. Он не отягощен применяемыми ранее в его истории приемами, поскольку до $\mathrm{XX}$ века его истории просто не существовало. Поэтому между кинематографом и массой возникают исключительные взаимоотношения. Кинематограф вводит в художественную жизнь те слои, которые вообще не имели в этом смысле никакого эстетического опыта.

Именно эти взаимоотношения оказываются исключительными не только по причине отсутствия навыков на предшествующих этапах коммуникации и с публикой и формирования доступного и понятного массе специфического языка, но и по причине тиражируемости произведения искусства. В этом смысле едва ли можно сравнить кино с каким - то другим видом искусства. Копии одного и того же произведения в принципе могут функционировать в сколь угодно широком пространстве. Хотя очевидно, что в первые десятилетия $\mathrm{XX}$ века кинематограф был исключительно городским зрелищем. Кинофикация деревни будет развертываться на протяжении 20-х годов, что в начале 30-х годов приведет к необходимости обновления киноязыка. Это тоже можно объяснить радикально изменившимся социальным составом публики и ее рецептивными навыками.

\section{2. Кинематограф как реабилитация архаического обряда. Миф кино в его втором значении.}

Говоря в предыдущей статье о рецепции кино в городской культуре России начала XX века, мы обратили внимание на то, как кино воспринималось по принципу чуда. Чудо же, как утверждал А. Лосев, свидетельствует о присутствии в рецепции мифа. Мы пока не расшифровали все смыслы возникновения этого чуда в его кинематографическом варианте. Дело в том, что с кино связан и еще один смысл чуда. Он связан уже не с техникой, позволяющей делать отпечатки реальности, причем, отпечатки не статические, а динамические. Другая сторона мифа кино связана с тем, что оно вернуло из древности формы зрелищ, что были одновременно и мифом, и обрядом или ритуалом. И реакции на такие древние ритуалы были связаны с трансформацией сознания, с очищением, катарсисом. На рубеже XIX XX веков мысль многих билась вокруг возвращения театра к его первоначальным истокам, в том числе, к формам древнегреческой трагедии, связанной с культом Диониса. Но возвращение театра к обряду - не самоцель. Это способ возродить утраченное чувство соборности, о которой рассуждают интеллектуалы Серебряного века.

Так, Вяч. Иванов приходил к выводу о преодолении той логики в развитии театра, что существовала на протяжении столетий, и возвращении к его исходной точке. А исходной точкой явился именно обряд, когда еще не было выделившихся из обрядового действия отдельных фигур - героев трагедии, а был лишь совершающий действие хор. Действие, следовательно, совершалось всеми участниками обряда. Такое возвращение к исходной точке для Вяч. Иванова позволило бы устранить пассивное созерцание действия, что и стало бы основным признаком рецепции театра и реабилитации действия как такового. Но это привело бы к упразднению рампы, разделяющей действующих на сцене актеров и зрителей [12, с. 37]. Но удивительно, что некоторым эта недостижимая в рамках театра соборность казалась достижимой в кино. Некоторым теоретикам и практикам кино разрешение задач этого рода тоже связывалось именно с кино.

Именно на кинематографе как соборном зрелище ставил акцент Л. Деллюк, сравнивая кинематограф с праздничными зрелищами в честь Диониса. Имея в виду кинематограф, он 
пишет: «У нас вдруг появилось настоящее народное искусство! У нас, у французов, которые никогда не имели его, и если имели, то только в виде пышных царственных представлений, - церемоний минувшего величия церковной роскоши. Да и весь цивилизованный мир не имел еще такого грандиозного зрелища после празднеств в честь Диониса! Неужели двадцать веков христианства не заметили или просто не заглушили эту потребность единения, потребность объединения бессознательных идеалов толпы в идеал, представленный в идее, танце или маске?» [9, с. 157].

Это, может быть, характерное для Л. Деллюка поверхностное восприятие кино как объединяющего массу зрелища углубляется, однако, в восприятии других интеллектуалов, когда они рассуждают о кино, особенно в сопоставлении с театров. Вот и А. Белый видит в кинематографе то, что является желаемым интеллектуалам Серебряного века, но что они в кинематографе еще не видят, полагая, что возродить эту соборность способен лишь театр [8, с. 155]. А вот А. Белый обнаруживает ее именно в кино, но никак не в театре. У него вообще можно фиксировать ироническое отношение ко всем попыткам возрождения древних мистериальных форм в театре [3]. Что касается кинематографа, то тут ирония исключается. «Синематограф - пишет А. Белый - сохраняя человеку его индивидуальность. Приобщает его к общему действу в гораздо большей мере, чем все теоретические постройки к соборному индивидуализму. Синематограф - демократический театр будущего, балаган в благородном и высоком смысле этого слова» [2, с. 351].

Такое восприятие кино как актуализации древнего очистительного обряда характерно для М. Волошина. Его восприятие кино тем более для нас значимо, что кинематограф он воспринимает разновидностью не только обряда, но и сновидения. «История возникновения театра из Дионисовых действ, так, как ее представляют в настоящее время - пишет М. Волошин - является в виде постепенного отказа участников священной оргии от активности посредством выделения из своей среды сперва хора, потом одного, двух и, наконец, многих актеров. Театр возникает из очистительных обрядов. Бессознательные наплывы звериной воли и страсти, свойственные первобытному человеку, пронзаются музыкальным ритмом и находят исход в танце. Здесь и актер, и зритель слиты во- едино. Затем, когда хор и актер выделяются из сонма, то очистительный обряд для зрителя перестает быть действием, а становится очистительным видением, очистительным сновидением. Зритель современный остается по-прежнему тем же бессознательным и наивным первобытным человеком, приходящим в театр для очищения от своей звериной тоски и переизбытка звериных сил, но происходит перемещение реальностей: то, что он раньше совершал сам действенно, теперь переносится внутрь его души. И сцена, и актер, и хор существуют реальным бытием лишь тогда, когда они живут, преображаясь в душе зрителя. Театр - это сложный и совершенный инструмент сна» [6, с. 35].

Театр, каким он предстает в своей поздней истории, конечно, далеко ушел от обряда, из которого он выделился. Но в том - то все и дело, что в начале XX века, когда театр оказался в кризисе, многие полагали, что он должен возродить самые ранние свои формы, которые от религиозного обряда отделиться не успели. Театр воспринимался в духе провозглашенной В. Соловьевым идеи теургии, смысл которой заключался в возвращении театра после того, как он эмансипировался от религии, снова в лоно религии. Иначе говоря, театр должен был снова вернуться к форме мистерии как религиозному обряду.

Правда, утверждая, что только мистерия позволит разрешить проблему массовости, сторонники такого взгляда не принимали в расчет того, что мистерия ориентирована на круг посвященных. Как свидетельствует $\Phi$. Шеллинг, «под мистериями, как известно, принято подразумевать существующие наряду с официальным богоучением (мифологией) и параллельно с ним идущее, тайное, сообщаемое лишь посвященным богоучение» [27, с. 130]. Собственно, и учение о Дионисе, которому посвящались мистерии, было тайным [27, с. 294].

Касаясь дискуссий этого рода, одну из своих статей М. Волошин посвятил соотношению обряда и театра. Он напоминает, что в древности обряд имел катартическое воздействие. Его миссия носила очистительный характер. Обряд предполагал участие в совместных актах многих. Это участие предполагало коллективное действие. Здесь не было разделения на действующих и пассивно воспринимающих. В дискуссиях начала XX века постоянно звучит идея упразднения этого разделения между действующими лицами и зрителями, а, как 
известно, оно стало значимым признаком освобождения театра от ритуала. По мысли М. Волошина, вместо действия, в которое в обряде вовлекаются его участники, в театре возникает видение или, еще точнее, сновидение. М. Волошин здесь абстрагируется от исторической ситуации. Между тем, для понимания того, почему театр предполагает безмолвное и пассивное восприятие, она важна. Ведь театр XIX века, когда происходит демократизация этого вида искусства, наполняет масса индивидов, которые в городской среде оказываются незнакомцами или чужаками. Это безличная масса. Касаясь ситуации, складывающейся в театре XIX века, Р. Сеннет обращает внимание на специфическую идентичность индивида, заполняющего театры XIX века. У него зритель предстает исключительно лишь наблюдателем, а не активным субъектом самовыражения [18, с. 219].

В этой ситуации функцией театра становится творчество сновидений, в которые погружается публика. Однако смена действия сновидением все же до конца не упраздняет очистительной или катартической функции театра. Поскольку обряд - это в то же время и миф, то, сохраняя очистительное свойство обряда, театр не перестает функционировать и как миф, имевший в древности не только художественную, но регулятивную функцию. Стало быть, театр, как и миф, продолжает оставаться предохранительным клапаном нравственного строя. Однако, по мысли М. Волошина, эту функцию с начала XX века в большей мере осуществляет даже не театр, а кинематограф. В эпоху нового варварства (и здесь М. Волошин подхватывает распространенную мифологему, происхождение которой связано с именем и Ф. Ницше) катартическую функцию могут осуществлять не утонченные традиционные искусства, к которым относится и театр, а именно кинематограф.

Если в театре зритель еще не окончательно разделен с актером, и, следовательно, действие здесь еще не целиком трансформируется в сновидение, то в кино это разделение происходит окончательно. Кино становится по - настоящему и исключительно видением и сновидением. В этом смысле кинематограф заменяет театр, как в Древнем Риме бои гладиаторов заменили греческую трагедию. Таким образом, смена действия сновидением в театре окончательно не упраздняется. В кино дистанция между актером и зрителем, которая в театре не была полностью все же упраздненной, и потому зритель не полностью себя идентифицировал с героем спектакля, кажется, исчезала совсем. Рецепция фильма устраняет разделение между актером и зрителем совершенно. Здесь восприятие базируется исключительно на идентификации с героем. М. Волошин пишет: «Мы видели, как в театре актер постепенно оттеснял зрителя со сцены для того, чтобы стать его сновидением. В синематографе эта линия завершается: зритель окончательно разделен с актером, - пред ним только одна световая тень действующего человека, безгласная, но одухотворенная нечеловеческой быстротой движений» [6, с. 39].

В выявлении этой особенности кино позднее близко подойдет А. Базен, делая ее в выявлении несходства между кино и театром определяющей. «Зритель в кино - пишет А. Базен - стремится отождествить себя с героем посредством психологического процесса, в результате которого зал становится «толпой», а эмоции унифицируются... Кино успокаивает зрителя, а театр - возбуждает. Даже тогда, когда театр обращается к самым низменным инстинктам, он все же до известной степени предотвращает формирование психологии толпы, он препятствует коллективному представительству в психологическом плане, ибо требует активного индивидуального сознания, тогда как фильм удовлетворяется пассивным сочувствием» [1, с. 170].

Чтобы аргументировать свою мысль о восприятии театрального действия как сновидения, М. Волошин прибегает к оппозиции дневного и ночного сознания. Но чтобы выявить сущность того и другого, ему пришлось поставить вопрос об истории развития сознания. Ведь человек не явился на свет уже обладающим готовым логическим или дневным сознанием. «Космические образы древнейших поэм и психологические самонаблюдения говорят о том, - пишет он - что наше дневное сознание возникло постепенно из древнего, звериного сонного сознания. Грандиозные, расплывчатые и яркие образы мифов свидетельствуют о том, что когда - то действительность иначе отражалась в душе человека, проникая до его сознания как бы сквозь туманную и радужную толщу сна» [6, с. 36].

Но, оказывается, овладев преимуществами дневного сознания, человек испытывает потребность возвращения в ночное сознание. Но это сознание как раз и означает регресс в миф, который активизируется в процессе ре- 
цепции фильма. Нечто подобное в сознании древнего грека улавливает $\Phi$. Ницше в своей ранней работе о происхождении трагедии. В заключение М. Волошин мистерию в ее кинематографических формах соотносит с атмосферой города. По его мнению, очистительная функция кино понятна лишь в этом контексте. Кинематограф очищает публику от нервной атмосферы большого современного города, Конечно, кинематограф в его настоящем виде пока далек от совершенства, но поэт верит в его великое будущее. «Когда власть над сновидениями всех городов Европы, - пишет он - перейдет из рук Пате и Гомона, в руки более изобретательных предпринимателей, для кино откроются новые возможности» [6, с. 40].

Очистительная или катартическая функция кино становится предметом внимания журналистов, которые оставили нам первые впечатления от посещения синематографа. Вот, например, один из них - Гейним, как бы подхватывая впечатления и суждения М. Волошина, продолжает мысль о действии кинематографа как наркоза, наркотика, позволяющего уйти из повседневности и созерцать сновидения. При этом соблазн кинематографа как сновидения Гейним объясняет опять же нервной атмосферой городской жизни. «Синематограф, рожденный как театр, как зрелище парижской улицей, воплотил в себе это безумие движения, - пишет он - Синематограф - самый характерный продукт современного города. Он сам - поток! Своим движением, стремительной сменой образов и настроений он увлекает за собой публику. Вот тайна его очарования, его притягательной силы. Нас тянет в синематограф, как парижанина тянет на улицу, в пьяную «духами и туманами» толпу. И здесь, и там - особый, сладостный наркоз. Наркоз движения, смешанного запаха цветов добродетели и зла. Синематограф концентрирует этот наркоз. Поэтому он потребен даже парижанину. И больше: чем значительнее город, тем более в нем процветает синематограф; хотя казалось, что должно было бы быть наоборот, т.к. в провинции он единственное развлечение. Но провинция более нормальна, более здорова. Она может опьяняться простой водкой. Ей не нужен гашиш. А парижанин, венец, москвич - опьяняющиеся ежедневно хмелем улицы, должны еще два раза, еще раз в неделю опьяняться сильней. Им мало разнообразия лиц и фактов - им нужна фантасмагория. Им мало причудливых образов в лиловом уличном тумане - им нужны видения.
Они идут в синематограф. Успокоительный мрак, желанный после разности электрических ламп, охватывает на мгновение синематографического зрителя. Но вот нервы его вздрагивают. Перед ним трогательная драма, захватывающая своими правдивыми подробностями. Он переживает вместе с героем его радости и несчастья. Он печалится; он страдает. Чувства, вызванные трагедией, доходят до апогея. И вдруг разряжаются комическими гримасами Макса Линдера. За минуту перед тем во власти тайных мук - он заливается веселым (но здоровым ли?) смехом, отдавшись неожиданным концепциям синематографической комедии. Он еще хохочет, инерция еще колышет его тело, когда синематографическая жизнь развертывает перед ним на серебряном экране подлинные события последней недели. Смотр войск в Лондоне, пожар в Чикаго, торжество в Бордо... Расстрел итальянцами пленных арабов в Триполи... Причудливый сон! Однако так импонирующий зрителю. Он нашел, что хотел. Голова его идет немного кругом. Он во власти тонкого, цинического наркоза» [7, с. 17].

Затрагивая рецепцию фильма как «сладостного гипноза», Гейним, по сути, касается еще одного значимого признака кино как компенсаторного фактора. Признак связан с нарастанием тех психологических процессов, что стали следствием города. Некоторые проявления этих последствий городской жизни считали неврастению. А Н. Васильев, например, в связи с урбанизационными процессами фиксировал даже переход в истории культуры от истерической фазы к фазе неврастенической. Согласно Н. Васильеву, в городе человек испытывает перманентное, хроническое переутомление нервной системы. Горожанин испытывает потребность в острых впечатлениях, что и обеспечивает кинематограф. Это - следствие того, что в городе нервная система утрачивает служебную роль и приобретает паразитарный характер [4]. Чтобы удовлетворить потребности нервной системы, возникают новые явления культуры. В этом удовлетворении кинематограф начинает играть первую роль.

\section{3. Миф кино как слагаемое мифа города. Миф в его третьем значении.}

Таким образом, мифы в раннем кино связаны не столько с сюжетами, сколько с собственно их рецепцией. Иначе говоря, на эти сюже- 
ты масса проецировала то, что было содержанием массового сознания. Следовательно, семантика фильма является не внутритекстовой, а внетекстовой. Иначе говоря, в сознании массы есть что-то такое, чего еще нет в самих сюжетах, в самих фильмах. Вот это что-то и оказывается в их восприятии определяющим. Независимо от намерений режиссеров раннего кино, фильмы наделялись какими - то смыслами, которые следовало бы разгадать. Такие смыслы, в частности, как раз и связаны с мифологией.

Что это за мифология? Откуда она берется? Вот тут - то нам и потребуется анализ массового сознания, которое вообще - то насыщено архетипическими образами, которые безразличны ко времени. Однако, как уже отмечалось, здесь потребуется принцип историзма. В том, что актуализируется в рецепции фильмов, когда масса наполняет синематографы первых десятилетий XX века, проявляется не вообще массовое сознание, а сознание массы, какой она предстает именно в этот период. В этот период представители массы - это мигранты в города. Это существенный фактор. В первых попытках понять природу нового способа коммуникации кинематограф связывается с городом. Это понятно. Первые кинозрители - это именно городская масса. Кинофикация деревни произойдет позднее, лишь в 20-е годы.

Но первые зрители - это не вообще горожане, а мигранты в города, т. е. вчерашние крестьяне. Чтобы соотнести кино и город и понять мифологические и архетипические мотивы массового сознания, необходимо предварительно понять, как вообще деревенское население воспринимает город. Необходимо иметь представление о существующем в сознании деревенского жителя образе города. Но если мы этот поймем, то получим ключ к содержанию той мифологии, что будет определять рецепцию раннего кино. Ведь первоначально кинематограф воспринимается в контексте не искусства, а городского образа жизни. «Попав в кино, человек эпохи символизма - пишет Ю. Цивьян - вступал в контакт не с фильмом и даже не с кинематографом, а с городом, сгущенным до состояния кинематографического текста» [26, с. 52]. Так, исследователь ссылается на А. Блока, для которого контакт с кино носил характер игры, в которой выбор фильма, кинематографа и даже решения зайти или не зайти в синематограф определялись обстоятельствами городской стихии.
Но для того, чтобы понять кинематограф как явление города, на которое проецируются те архетипы, что сопровождают историю города, необходимо эти архетипы выявить. «Город в истории одновременно и настолько новое явление, - пишет Вяч. Вс. Иванов - что каждое последующее поколение заново начинает ему изумляться, и настолько древнее, что это удивление передается нередко образами многотысячелетнего возраста» [13, с. 24]. Но это суждение относится к городу вообще. Что касается России первых десятилетий $\mathrm{XX}$ века, то в это время кинематографическими столицами предстают Москва и Петербург. Сказанное Вяч. Вс. Ивановым применительно к городу вообще необходимо соотносить с неодинаковым отношением населения России к каждому из названных столиц. Так, Петербург воспринимался казенным, казарменным, регулярным, официальным и неуютным городом, Москва же, наоборот, казалась уютной, естественной, патриархальной, семейной и интимной [20, с. 7].

Так, отсутствие у Петербурга истории способствовало исключительной мифологизации этого города. Нередко он воспринимался призрачным, фантасмагорическим пространством. С другой стороны, он был образцом рационалистической утопии. Ю. Лотман называет город, любой город котлом текстов и кодов, принадлежавших разным языкам и разным уровням [15, с. 35]. Это касается и Петербурга. Присутствие множества сопровождающих его рецепцию текстов и кодов оказывается стимулирующим творческим фактором. Так, Ю. Лотман пишет: «К 1830-м годам Петербург сделался городом культурно - семиотических контрастов, и это послужило почвой для исключительно интенсивной интеллектуальной жизни» [15, с. 44]. Доказательством этой мысли может служить и город рубежа XIX - XX веков, в контексте которого возникала и элитарная культура Серебряного века, и кинематограф как массовый вид искусства.

\section{4. Миф кино как слагаемое мифа города. Кинематограф сквозь призму фольклорного сознания.}

Соотнося рецепцию фильмов на раннем этапе истории кино с образом города, мы получаем еще один, второй уровень мифологического мышления. Известно, что, возникая, кинематограф очень быстро получает 
распространение. Первоначально его мыслили как что - то вроде технического средства, необходимого для развития науки. Однако изобретением мгновенно воспользовалась масса, наделяя его своими психологическими комплексами.

Как уже отмечалось, первыми посетителями синематографов были представители демократических низов города, в которых преобладали вчерашние крестьяне, зрители - мигранты из деревень. Это определяет рецепцию ими города как утопического пространства, воспринимающегося по контрасту с деревенским образом жизни. Такой утопический образ города формировался на протяжении столетий. Интенсивные урбанизационные процессы способствовали соприкосновению с этим утопическим городским пространством, которое, как казалось, стало реальностью. Естественно, что кинематограф воспринимался и продолжением этого утопического образа города и его выражением. Можно утверждать, что отныне крестьянин - мигрант оказывается в пространстве созданного в доиндустриальном обществе мифа, городского мифа. Так, если город соотносился с загробным миром, то, соответственно, и изображение на экране воспринималось в соответствии с этим миром, т.е. как актуализация образов загробного мира.

Теперь самое время перейти к морфологии сознания массы, как она актуализируется в формах кинематографа. Конечно, приток в города массы мигрантов неизбежно приводит к вспышке устной культуры и, следовательно, к некоторому регрессу в состоянии тех культурных образований, которыми к этому моменту располагал город. Вспышка устной коммуникации связана с втягиванием фрагментов культуры доиндустриального общества в культуру индустриального общества. Эта вспышка означает фольклоризацию сознания как разновидности мифологического сознания. Вчерашний крестьянин воспринимает все, что в настоящем происходит сквозь призму фольклора. Конечно, в городе этот язык фольклора подвергается трансформации, превращаясь в то, что фольклористы называют городским фольклором, что начинает определять и кинематограф [22, с. 66], [23], [24].

Так, исследователь ранней рецепции кино утверждает, что киноаудиторию 1900-х годов можно рассматривать как близкую миру городского фольклора [26, с. 135]. Конечно, в последующие десятилетия в киноаудитории происходят заметные сдвиги. Однако фольклорная константа рецепции продолжает оставаться. «Однако - пишет Ю. Цивьян - если в 1900-е годы экспансивность аудитории можно вывести из ее социального и возрастного состава, то для более позднего времени эта зависимость прослеживается слабее. В 1910 - е годы кинематограф перестал быть прерогативой городских низов, однако норма поведения во время сеанса существенно не изменилась. Фольклорный по своему генезису «демократический» тип поведения закрепился за кинозалом как особым пространством городской культуры» [26, с. 137].

В чем же конкретно проявляются рецептивные горизонты зрителей, определяемые фольклором? Вот тут - то мы как раз и должны обратить внимание на связь рецепции кино с установкой на фольклор с рецепцией города. В этой последней рецепции определяющую роль тоже играет фольклор. Правда, когда мы говорим о фольклоре, то здесь следует учитывать то обстоятельство, что в городе фольклор, возникший в крестьянской среде, видоизменяется и получает название городского фольклора. Но изменения касаются также возвращения фольклора к своей исходной точке, т.е. к мифу. Фольклорные тексты, как известно, еще сохраняют связь с мифом, но они уже отрываются от него и осуществляют развлекательную, игровую функцию. В переходе от фольклора к литературе она превратится в одну из определяющих функций. Такова логика секуляризации в индустриальных обществах.

С другой стороны, сохраняя связь с пратекстом, т.е. с мифом, фольклор в результате этой связи не утрачивает до конца своего сакрального смысла. Ведь миф - транслятор исключительно сакрального смысла. В фольклоре оппозиция «сакральное - игровое» предстает такой, что игровая стихия в ней выходит на первый план. В городской среде как среде секулярной среде происходит видоизменение фольклора в сторону развлечения и игры. Но, с другой стороны, город провоцирует и взрыв сакрального начала, что, например, предстает в апокалиптических настроениях и слухах, что имело место и в начале XX века. Кстати, когда С. Булгаков пытается понять ранние формы апокалиптики, он утверждает, что она получает выражение в фольклорных формах.

Итак, чтобы понять, как конкретно в кино проявляет себя фольклорное сознание, 
мы не сможем избежать вопроса о массовой рецепции города, которая тоже оказывается фольклорной. Получая выражение в разных формах, образ города затем предстает в кинематографическом выражении. Но, констатируя актуализацию фольклорного сознания, касающегося рецепции города, мы не должны забывать, что ядром этой рецепции все же является миф. Кинематограф - это слагаемое существующего в сознании мигранта мифа о городе. Лишь получая доступ к этому мифу города, мы получаем информацию о массовой рецепции раннего кино.

Видимо, в сознании мигранта определяющим ядром городского мифа будет образ города как пространства свободы, счастья и изобилия. Такой образ создается, конечно, по контрасту с той реальностью, в которой существует житель деревни. С этим мифологическим образом города и связан мотив утопии. Существуя в традиционной культуре, сельский житель ощущал контроль этой культуры, иерархию и структуру деревенского социума. Чтобы это бремя выносить, он должен был хотя бы на короткое время выходить из этой структуры, освобождаться от бремени. Для этого в традиционной культуре существовала праздничная культура, в которой царила атмосфера лиминальности, т.е. выхода в пространство свободы и игры.

Становление индустриальной цивилизации привело к динамичному пространственному перемещению. Атмосфера лиминальности стала уже ассоциироваться не с праздничным календарем, вообще, с временем, а с пространством, а именно, с городским пространством вообще, с городом. Если миграцию в города связывать лишь с экономическим фактором, то мы не уловим ментального, т.е. лиминального смысла. Но это и есть мифологический смысл. Оказываясь в городском пространстве, мигрант это пространство воспринимает как реализуемую утопию. У Е. Трубецкого есть удивительно талантливая работа, посвященная соотношению образов русской сказки с тем, что происходило после революции 1917 года, да, полагаю, и до этой революции тоже. В сказках Е. Трубецкой, в частности, обнаружил желаемую атмосферу разгула как синонима понимания русским человеком праздника, что воспроизводилось на уровне сюжетов и жанров раннего кино. «Большое внимание уделяется сказкой и жизненному идеалу простого человека, который очерчивается довольно яркими штрихами - пишет Е.
Трубецкой - Это, прежде всего, мечта о том веселом житье, которое олицетворяется царским пиром: «свадьба королевича была веселая, все кабаки и трактиры на целую неделю были открыты для простого народа безденежно». В сказке о бедном и слепом рассказывается, как царь поручил мужику добыть ему невесту «краше солнца» и посулил за то сделать его первым министром, но наперед разрешил мужику «погулять», выдал ему «открытый « лист за своим подписом, чтобы во всех трактирах и харчевнях отпускали ему безденежно всякие напитки и кушанья. Мужик прогулял три недели. Этот народный разгул вообще одна из любимых тем русской сказки; вся социальная утопия сказки окрашивается, прежде всего, стремлением наесться и нажиться вволю» [21, с. 103].

Почему же такое внимание разгулу и, в том числе, обжорству и пьянству? Да потому, что этому образу разгула предшествовали в архаические эпохи внедренные обрядовые установки. Как отмечает В. Пропп, обжорство имело магические функции. «Еде во время обрядовых праздников приписывали особое значение. Два раза в году - под новый год и на масленицу - поголовно все население, в меру своих средств стремилось наесться, причем, не просто много ели, а ели как можно больше, без всякой меры. Такая неумеренность под Новый год объясняется поверьем, будто обилие еды в первый день Нового года обеспечивает обилие на весь год» [16, с. 25].

Перед тем, как стать мотивом повествования, образ праздничного разгула первоначально определяет рецепцию города носителем массового сознания. Поскольку же синематограф вписан в городское пространство, то миф города проецировался и на синематографы. Содержание этого мифа связано с праздничным разгулом или, еще точнее, пониманием свободы, достижимой лишь на время праздника. Праздничное время - это время, которое, в соответствии с концепцией В. Тернера, является лиминальным. Лиминальность - это состояние выхода за пределы организованного общества, в котором поведение людей регламентировано жесткими нормами и правилами [19, с. 171]. Но это состояние выхода - временное состояние. После окончания праздника все снова входит в берега, все функционирует в соответствии с нормами общества.

Поскольку праздничное время в доиндустриальных обществах в календаре занимало 
достаточно много места, то невольно возникает вопрос. Какой смысл имели эти праздники, к которым человек и архаической, и традиционной культуры возвращался? Когда мы начинаем в этом разбираться, мы невольно приходим к выявлению праздничного архетипа, сквозь призму которого воспринимается город. Но этот праздничный архетип оказывается в то же время и реальностью мифа. Дело в том, что любое общество, придерживающееся норм и правил, позволяющих поддерживать порядок, стареет и разрушается. Противоречия могут распространяться и углубляться. Существование людей оказывается под угрозой. Поэтому, чтобы противостоять распаду, общество должно вернуться к своей исходной точке, когда социум как упорядоченный и организованный космос еще не существовал, а существовал лишь хаос. Иначе говоря, космос возникал из хаоса и лишь постепенно обретал структуру и упорядоченность.

Возвращение в праздничное время к исходной точке является одновременно и возвращением в мифологическое время. Чтобы укрепить порядок и единство общества, необходимо все начать с начала, вернуться в то время, когда героические предки начали создавать космос из хаоса. Собственно, смысл праздничного времени как раз и заключается в возвращении в те далекие времена, когда космос предками был сотворен из хаоса. Праздничные акции должны повторить это сотворение космоса снова. Но, конечно, в форме обрядовых действий. Вот почему маска неизменный атрибут праздника. Ведь человек в маске представляет героического предка. Поскольку праздничное время - это мифологическое время, то оно предполагает отрицание исторического времени. А в мифологическом времени, в котором дифференциация времен упраздняется, предки снова оживают. Так возникает образ праздника как золотого века. За этими мифологическими представлениями скрываются непростые отношения между культурой и природой. Возвращение в мифологическое время - это реабилитация не только хаоса, это не только упразднение норм, но это и возвращение в природную стихию, права которой потеснены культурой, a, еще точнее, цивилизацией.

Применительно к городу и выражающему его стихию кинематографу здесь важно отдавать отчет о совмещении при восприятии города как праздника двух его образов - образа города как золотого века и образом города как хаоса. Это совмещение многое объясняет и в отношении к русскому городу рубежа XIX - XX веков. Соответственно, эта амбивалентность в восприятии города многое в рецепции и кино объясняет. С одной стороны, восприятие города как материализовавшегося образа золотого века порождало ощущение изобилия и счастья. «Человек с ностальгией оглядывается на мир, - пишет Р. Кайюа - где достаточно было протянуть руку, чтобы нарвать сладких и вечно зрелых плодов, где урожай сам послушно складывался в житницы без пахоты, сева и жатвы, где не было суровой необходимости труда, где желания осуществлялись едва возникнув, не искажаясь, не сокращаясь и не уничтожаясь какой-либо материальной невозможностью или же социальным запретом» [14, с. 225]. Получается, что праздник это земной рай, где все достается даром. Здесь нет войн, нет рабства, частной собственности, коррупции.

С другой стороны, праздник - это мир света, безмятежных радостей, легкой и счастливой жизни представал и другой стороной, связанной с мраком и ужасом. «Эти два антагонистических представления иногда неразличимо смешиваются, иногда разделяются в силу тяги человеческого ума к связной последовательности - пишет Р. Кайюа - и тогда мифология различает, противопоставляет Хаос и Золотой век, располагает их один за другим. Они предстают как две стороны одной и той же воображаемой реальности - неупорядоченного мира, из которого вышел мир упорядоченный, где живут нынешние люди. Он противостоит этому последнему как мир мифа - миру истории, начавшейся с концом мифа. Он противостоит ему также как мир снов (чье имя он часто и носит) - миру яви. Наконец, он представляет собой время безделья, изобилия, расточительности, которые человек тщетно надеется вернуть, будучи обречен на труд, нехватку и бережливость» [14, с. 225].

Запомним это отношение к празднику, поскольку оно будет актуализироваться в восприятии не только города, но и кинематографа. Однако любопытно, что этот образ праздничного разгула пока для кино был внешним образом. Его происхождение связано отнюдь не с кинематографом. Такой образ, столь активный для горожанина в первом поколении, т.е. крестьянина - мигранта явился следствием его отношения не к кино, а к городу. Для него таким праздничным разгулом воспринималась, прежде всего, вся городская жизнь. 
Такой образ города сформировался отнюдь не на рубеже XIX - XX веков, а гораздо раньше. Функционирование такого образа характерно для всей истории доиндустриального общества. Но понятно, что на рубеже XIX-XX веков из чисто ментального он трансформируется в реальный. Вот тут - то возникает когнитивный диссонанс, и будет вызвана к жизни та психология ressentiment, которая приведет к катастрофам в политической истории.

Первоначально же мигрант, находясь уже в городе, ищет подтверждения в нем мифа с его крестьянским содержанием. Содержание фильмов должно этот миф подтвердить. Вот почему Ю. Цивьян утверждает, что для посетителя синематографов в 1900 - 1910-е годы кино ассоциировалось с дешевой роскошью, итеративностью эмоций, причастностью к порочному и преступному миру, исключительной принадлежностью к городскому быту, к низовому эгалитаризму. «В сознании кинозрителя начала века, - пишет он - складывался образ кинотеатра как пространства, совмещающего в себе привкус запретного и доступного, пространства, где на «дешевых местах» может оказаться, что ты сидишь рядом с экс - королем Португалии. Иначе говоря, пространство кинотеатра приобретало черты, роднящие его с фантастическим миром экрана» [26, с. 58].

Спрашивается, если кинотеатр воспринимается в соответствии с мифом города, то, как же воспринимаются сами фильмы? Имеет ли этот существовавший в сознании вчерашнего крестьянина миф отношение к содержанию фильмов? Разумеется, имеет. Здесь на пер- вый план выходит мотив соблазна. При ответе на эти вопросы обратимся к проделанному Н. Зоркой исследованию сюжетов раннего русского кино по методу В. Проппа. Определяющим мотивом сюжета в раннем кино становится соблазн и, соответственно, появление персонажей - соблазнителя и соблазненной. «Явление обольстителя обычно предваряется соблазном - пишет Н. Зоркая - Обольститель редко падает на голову персонажей как снег на голову, редко вторгается сразу в то благополучие, которое мы назвали начальной или исходной ситуацией. Должен сначала возникнуть некий соблазн, который поставит героя перед опасностью, а уж ее тот опрометчиво не заметит или легкомысленно недооценит. Часто этот соблазн возникает просто потому, что герой покидает свое добровольное убежище укрытие и отправляется туда, где его со всех сторон поджидают пороки, вихри, страсти и преступления. Такие вертепы - в первую очередь столица, резко противопоставленная добродетельной провинции и деревне; артистическая среда, благотворительный базар, ужин в ресторане, драматическая школа, богатые дома, театр и даже симфонический концерт (важна уже просто смена обстановки - добропорядочной на порочную или чреватую увлечениями)» [11, с. 200].

Таким образом, расцвету мелодрамы в раннем кинематографе мы также обязаны актуализации в кино мифа. Актуализация мифа во внесюжетных и внежанровых связях постепенно проникают в сюжеты и жанры. Так начинается история кино.

\section{Библиография:}

1. Базен А. Что такое кино? М., 1972.

2. Белый А. Синематограф //Белый А. Арабески. М., 1911.

3. Белый А. Театр и современная драма // Белый А. Символизм как миропонимание. М., 1994.

4. Васильев Н. Вопрос о падении Западной Римской империи и античной культуры в историографической литературе и в истории философии в связи с теорией истощения народов и человечества // Известия общества археологии, истории и этнографии при Казанском университете. т. ХХХІ., Выпуск 1-4., Казань., 1920.

5. Вебер А. Рост городов в ХІХ столетии. СПб., 1903.

6. Волошин М. Мысли о театре // Аполлон., 1910., № 5.

7. Гейним. Синематограф и театр // Сине-фоно., 1913., № 23.

8. Гуревич Л. Заметки о современной литературе. Мечты и мысли о новой драме // Русская мысль., М., $1910 .$, № 4.

9. Деллюк Л. Фотогения кино. М., 1924.

10. Зоркая Н. Кинематограф в жизни Александра Блока // Из истории кино. Выпуск 9., М., 1974.

11. Зоркая Н. На рубеже столетий. У истоков массового искусства в России 1900-1910-х годов. М., 1976.

12. Иванов Вяч. Предчувствия и предвестия // Иванов Вяч. Родное и вселенское. М., 1994.

13. Иванов Вяч. Вс. К семиотическому изучению культурной истории большого города // Семиотика пространства и пространство семиотики. Труды по знаковым системам. Выпуск 19., т. 664., Тарту., 1986. 
14. Кайуа Р. Миф и человек. Человек и сакральное. М., 2003.

15. Лотман Ю. Символика Петербурга и проблемы семиотики города // Семиотика города и городской культуры. Труды по знаковым системам. Выпуск 18., т. 664., Тарту., 1984.

16. Пропп В. Русские аграрные праздники. Л., 1963.

17. Психология театральной толпы // Театр и искусство. 1898., № 5.

18. Сеннет Р. Падение публичного человека. М.. 2002.

19. Тернер В. Символ и ритуал. М., 1983.

20. Топоров В. Петербург и петербургский текст русской литературы // Труды по знаковым системам. Выпуск 18., т. $664 . .1984$.

21. Трубецкой Е. «Иное царство» и его искатели в русской народной сказке // Литературная учеба. 1990., № 2-3.

22. Хренов Н. Кино в функции формирования и поддержания коллективной идентичности // Кино и коллективная идентичность. М., 2013.

23. Хренов Н. Социально-психологические аспекты взаимодействия искусства и публики. М., 1981.

24. Хренов Н. Кино: реабилитация архетипической реальности. М., 2006.

25. Чуковский К. Нат Пинкертон и современная литература. М., 1910.

26. Цивьян Ю. Историческая рецепция кино. Кинематограф в России. 1896-1930. Рига., 1991.

27. Шеллинг Ф. Философия мифологии., т. 2. СПб., 2013.

\section{References (transliterated):}

1. Bazen A.Chto takoe kino? M., 1972.

2. Belyi A. Sinematograf//Belyi A. Arabeski. M., 1911.

3. Belyi A. Teatr i sovremennaya drama // Belyi A. Simvolizm kak miroponimanie.M., 1994.

4. Vasil'ev N. Vopros o padenii Zapadnoi Rimskoi imperii i antichnoi kul'tury v istoriograficheskoi literature i v istorii filosofii v svyazi s teoriei istoshcheniya narodov i chelovechestva // Izvestiya obshchestva arkheologii, istorii i etnografii pri Kazanskom universitete. t. KhKhKhI., Vypusk 1-4., Kazan’., 1920.

5. Veber A. Rost gorodov v KhIKh stoletii. SPb.,1903.

6. Voloshin M. Mysli o teatre // Apollon., 1910., № 5.

7. Geinim. Sinematograf i teatr // Sine-fono., 1913., № 23.

8. Gurevich L. Zametki o sovremennoi literature. Mechty i mysli o novoi drame // Russkaya mysl',, M., 1910., № 4.

9. Dellyuk L. Fotogeniya kino. M., 1924.

10. Zorkaya N. Kinematograf v zhizni Aleksandra Bloka // Iz istorii kino. Vypusk 9., M., 1974.

11. Zorkaya N. Na rubezhe stoletii. U istokov massovogo iskusstva v Rossii 1900-1910-kh godov. M., 1976.

12. Ivanov Vyach. Predchuvstviya i predvestiya // Ivanov Vyach. Rodnoe i vselenskoe. M., 1994.

13. Ivanov Vyach. Vs. K semioticheskomu izucheniyu kul'turnoi istorii bol'shogo goroda // Semiotika prostranstva i prostranstvo semiotiki. Trudy po znakovym sistemam. Vypusk 19., t. 664., Tartu., 1986.

14. Kaiua R. Mif i chelovek. Chelovek i sakral'noe. M., 2003.

15. Lotman Yu. Simvolika Peterburga i problemy semiotiki goroda // Semiotika goroda i gorodskoi kul'tury. Trudy po znakovym sistemam. Vypusk 18., t. 664., Tartu., 1984.

16. Propp V. Russkie agrarnye prazdniki.L., 1963.

17. Psikhologiya teatral'noi tolpy // Teatr i iskusstvo. 1898., № 5.

18. Sennet R. Padenie publichnogo cheloveka. M.. 2002.

19. Terner V. Simvol i ritual. M., 1983.

20. Toporov V. Peterburg i peterburgskii tekst russkoi literatury // Trudy po znakovym sistemam. Vypusk 18., t. 664.. 1984.

21. Trubetskoi E. "Inoe tsarstvo" i ego iskateli v russkoi narodnoi skazke // Literaturnaya ucheba. 1990., № 2-3.

22. Khrenov N. Kino v funktsii formirovaniya i podderzhaniya kollektivnoi identichnosti // Kino i kollektivnaya identichnost'. M., 2013.

23. Khrenov N. Sotsial'no-psikhologicheskie aspekty vzaimodeistviya iskusstva i publiki.M., 1981.

24. Khrenov N. Kino: reabilitatsiya arkhetipicheskoi real'nosti.M., 2006.

25. Chukovskii K. Nat Pinkerton i sovremennaya literatura. M., 1910.

26. Tsiv'yan Yu. Istoricheskaya retseptsiya kino. Kinematograf v Rossii. 1896-1930. Riga., 1991.

27. Shelling F. Filosofiya mifologii., t. 2. SPb., 2013. 